\title{
AN EXAMINATION OF JOHN RAVEN'S SURVEY OF THE ESSEX ESTATE
}

\author{
by \\ Dr P. J. Duffy
}

In his Realities of Irish Life, published in 1868, when describing the origins of the Shirley estate in the Barony of Farney in Co. Monaghan, William Steurt Trench refers to the completion in 1636 of a survey,

"probably the first ever made of the barony, and a beautiful set of maps were laid on vellum, executed in a masterly manner. This survey and set of maps complete, giving all the denominations of the several lands very nearly corresponding with the names at present in use, are now in existence, carefully bound up in a large volume, and are still in perfect preservation at Longleat, the seat of the Marquis of Bath in Wiltshire, the present owner of one moiety of the barony".

Trench is here referring to what was in many ways a pioneering survey of Farney, completed in fact in 1635, by Thomas Raven, for the Earl of Essex, and fortunately continuing in an excellent state of preservation in the library at Longleat. It is interesting that E. P. Shirley was unaware of this survey when he published his history of Farney in $1845,{ }^{2}$ but it was he presumably who made a copy in 1872 of the Shirley part of the estate survey, which is listed among the holdings of the Shirley Library at Lough Fea House in 1958 as a survey of the western moiety of the barony of Farney, containing forty two plates "crudely but vividly coloured". ${ }^{3}$

Raven's Survey of Farney is an extremely important and valuable document not only because it represents one of the earliest estate surveys in Ireland and is thus an important landmark in the history of cartography and land surveying in Ireland, but also because it provides some tantalising clues about the shape and organisation of an Irish landscape in the early seventeenth century, before the processes of landscape modernisation had got underway. The following short paper consists of a description of the contents of Raven's survey, and an assessment of its usefulness as a depiction of patterns of settlement and landscape in $1634 .^{4}$

Thomas Raven, " perhaps the most gifted cartographer to make his home in early seventeenth century Ireland", ${ }^{5}$ was one of a small number of official cartographers employed by the English administration to survey and map lands confiscated in the Ulster Plantation. Following the establishment of the Ulster Plantation, Raven turned his talents to surveying and mapping on a private basis

1. W. Steurt Trench, Realities of Irish Life, London 1868, 68.

2. E. P. Shirley, Some Account of the Territory or Dominion of Farney. London, 1845.

3. Analecta Hibernica, No. 20, 263. I have been unable to trace this copy.

4. Based on a six hour examination of the maps in Longleat Library in July 1982.

5. John H. Andrews, Irish Maps, Dublin, 1978, 15. 


\section{Clogher Record}

for many of the new and enterprising landowners of the period. He was employed, for example, by the London Companies in 1615 to map their lands in the County of Derry, ${ }^{6}$ and his name occurs in association with surveys in the de Renzi estates in King's County in the 1620's and 1630's, in a survey of the Egmont Estates in Munster and finally in the Strafford Survey in $1635 .{ }^{7}$ Raven, largely unrecognised at the time, appears as an inventive and innovative surveyor, who spent a lot of his time endeavouring to obtain a permanent civil service position as a "controller of the admeasurements", ${ }^{8}$ a reflection probably of the financial insecurity of cartography and surveying at the time. Cartographically, the seventeenth century is dominated on the one hand by the surveys of the Ulster Plantation counties and on the other by the Down Survey of 1654. Both undertakings, concerned with the efficient allocation of confiscated lands, were principally aimed at the identification and measurement of property boundaries. The plantation maps although unprecedented in form and style, were quite sketchy; ${ }^{9}$ the Down Survey which continues as a landmark of historical and of geographical significance, was more detailed and attempted to provide some information on settlement and land quality.

Raven's Survey of Farney in 1634 is therefore all the more remarkable because in its detailed depiction of the contemporary landscape, it was well before its time, presaging to a great extent the later estate surveys of the eighteenth century. The eighteenth century and particularly the latter half of it, was characterised by an upsurge in estate maps and surveys reflecting one aspect of increased interest and investment by landowners in their properties at a time of rapidly improving economic conditions in agriculture. Before the advent of the Ordnance Survey in the 1830 's with its high quality six-inch survey, these estate maps which varied greatly in quality and usefulness, were the only maps of local landscapes. Classic examples of such maps are those by Rocque and Scale, ${ }^{10}$ but a more modest and typical example is the survey of the Dawson estate in Co. Monaghan by Daniel Hanley in 1768. ${ }^{11}$ " Many of the techniques and much of the information provided in his maps, for example, were presented effectively by Raven 130 years earlier in Farney.

Comparatively few estates would have been sufficiently stable or viable to warrant detailed mapping in the seventeenth century. Farney was somewhat exceptional. Following the turmoil in Ulster in the latter part of the sixteenth century, Monaghan county missed the upheavals in landownership which accompanied the Plantation. ${ }^{12}$ The early grant of Farney to Essex in 1575 ensured stability of ownership well into the seventeenth century. The Essex estate, one of

6. John H. Andrews, The maps of the escheated counties of Ulster 1609-10, Proceedings of the Royal Irish Academy, 74c (1974), 143, 166.

7. See D. A. Chart (ed) Londonderry and the London Companies, 1928; G. Camblin, The Town in Ulster, 1951. R. Gillespie, Thomas Raven and the mapping of the Claneboy estates, Journal of the Bangor Historical Society, 1 (1981).

8. Andrews, op. cit., 166.

9. Ibid.

10. Andrews, Irish Maps.

11. This volume of maps by Hanley is in Monaghan County Museum.

12. P. J. Duffy, Patterns of Landownership in Gaelic Monaghan in the sixteenth century, Clogher Record X (1981) 3. 
the most extensive in the country at more than 47,000 acres, was occupied by Ever McColla McMahon from the 1590's (at times from the Crown's viewpoint, illegally, although Essex had little opportunity or interest in managing his property in the sixteenth century). It was leased in 1606 by the young Earl of Essex to McMahon, who appears to have administered it effectively and profitably, until his death in 1617. By then, the barony had more than trebled in value. ${ }^{13}$ From 1618 until the $1650^{\prime}$ s, the estate was leased in several large sections to a number of undertakers, including Coll McBryan McMahon (grandson of Ever), who were enjoined, as was the practice in the Ulster Plantation counties to build a "strong and substantial house of stone or brick . . . after the English manner . . . to be covered with slate or tyle" and to fence and enclose all or part of their property within ten years. ${ }^{14}$ As in much of Ulster, the English undertakers in Farney had a particular difficulty in occupying their lands and obtaining rents from their tenants. Shirley quotes one of them in 1625 , referring to his sturdy stone houses being necessary for protection from "thieves and rebells". He also refers to a practice of making proclamations to the tenants at market days and "at the masse" 15 - reflecting a degree of normality of living conditions that most commentators omit. It was at this time of some stability and estate development in Farney and in Ulster generally that Essex undertook a thorough assessment of his property in Monaghan and engaged the experienced Thomas Raven to conduct his survey in 1634. It is suggested in fact that Essex who was short of cash at the time, was considering selling his Monaghan properties. ${ }^{16}$

The title page of Raven's Survey outlines its scope and content:

An exact and perfect survey and admeasurement of the landes belonging to the Right Honourable Earl of Essex and Ewe lyeing in the County of Monaghan in the Kingdom of Ireland taken and made by Thomas Raven surveyor according to the Bounds and Meares of the several Tathes of lands then showed and set forth to be measured with the several quantities and qualities of the several partes of each Tathe according to the nature of the lands distinguishing the erable and pasture pasturable woods and mountains from those that were waste and unprofitable and also noting such lands as are in controversy with his Lp and his bounding neibours with the description of all Loughs or standing pools of water, water courses, mills, highways, buildings and other things of note contained in the said territories described at large according to the statute English acre of 16 foot \& half to the Pearch ... performed in Anno 1634 \& in $1635 .{ }^{17}$

The Survey consists of a folio volume of maps in sheets numbered up to 67 (including two number 11), each covering two pages, the back of each of which contains a table of references to land use and quality by area in each tate. There is a separate un-numbered sheet of Carrickmacross drawn on a larger scale than the remaining 'tate' maps. In general from two to six contiguous tates appear on each sheet, with the exception of the last sheet which shows five isolated individual tates. The boundaries of the tates are coloured in different shades. Hills are drawn

13. E. P. Shirley, Farney, 122.

14. Ibid., 125-6.

15. Ibid., footnote, 126.

16. See Gillespie, op. cit.

17. Some spellings have been modernised. 


\section{Clogher Record}

in and coloured brown, rivers blue, some roads are coloured yellow or brown, boggy land is coloured brown. Many trees are shown in profile. Houses, cabins, churches, mills, ponds etc., are shown with a reasonable attempt at realism.

Fig. 1 shows the extent of Raven's survey in relation to the modern map of townlands. The Essex Estate covered most of the barony of Farney, with the exception of the parish of Iniskeen, which was held by the Archbishop of Armagh, and a number of other churchlands referred to in Fig. 1. The accuracy of Raven's survey of the estate is indisputable. Of 309 townlands in the area of the Essex estate that are identifiable in the Ordnance Survey map and which continue in use today, 271 can be easily identified in Raven's survey and 29 can be identified by means of shape and the names of surrounding tates. In addition a number of tates listed in Raven have been subsumed by neighbouring townlands (see Index to Fig. 1). Altogether nine modern townlands could not be fitted into Raven's Survey. Although it was not possible to check the detailed acreages given for each tate by Raven to see if they corresponded with the modern townlands, in a great many cases the necessarily cursory examination of the survey at Longleat indicated that the shape and extent of the seventeenth century tates tallied closely with the modern townlands. Some of the boundaries, especially bordering on the barony of Cremourne and the County of Cavan, were noted as being "in controversie".

Fig 2, shows the distribution of some of the settlement features included in Raven's maps. Each item has been located in approximately the correct position within each townland (or tate).

The following principal items were counted :

$\begin{array}{lrrlr}\text { Cabins } & - & 423 & \text { Churches } & - \\ \text { 'Houses' } & - & 23 & \text { Crosses } & - \\ \text { Mills } & - & 6 & \text { Fords } & -\end{array}$

To this must be added a further fifty two cabins and five houses for Carrickmacross town (in addition to the Castle). Roads or 'waies' proved difficult to copy; they seemed suspiciously concentrated in the south-western part of Farney, the last half of the survey, as if Raven only decided to include them at this latter stage of his undertaking. The road pattern insofar as it was decipherable, was extremely interesting because in many cases it seems to reflect the existing modern road net. In a lot of cases the roads are marked as 'the way to Monohan/Ardee' etc. There were other interesting reflections of communications. Paths through 'bogges' for instance were referred to as 'cash' and one in Toome townland was written-in as 'cash do na mara', indicating that Raven took account of local information.

Two main types of habitation are clearly shown in the survey. 'Cabins' and 'houses' have been differentiated in this paper solely on the basis of their appearance in the maps. Cabins were quite numerous and houses were comparatively few. Cabins in the main are shown as single-storied structures with a door and, occasionally, windows although sometimes neither door nor window. Their roofs are coloured yellow indicating thatch. They most often were in formless clusters of from two to six in number, without any accompanying features. There is of course, no indication that these are residences as opposed to other types of building. But it seems reasonable to assume, that they are ordinary dwellings. 'Houses' are generally depicted with two storeys, blue/black roofs and often with what appear to be dormer-style windows. In contrast to the numerous cabins, 


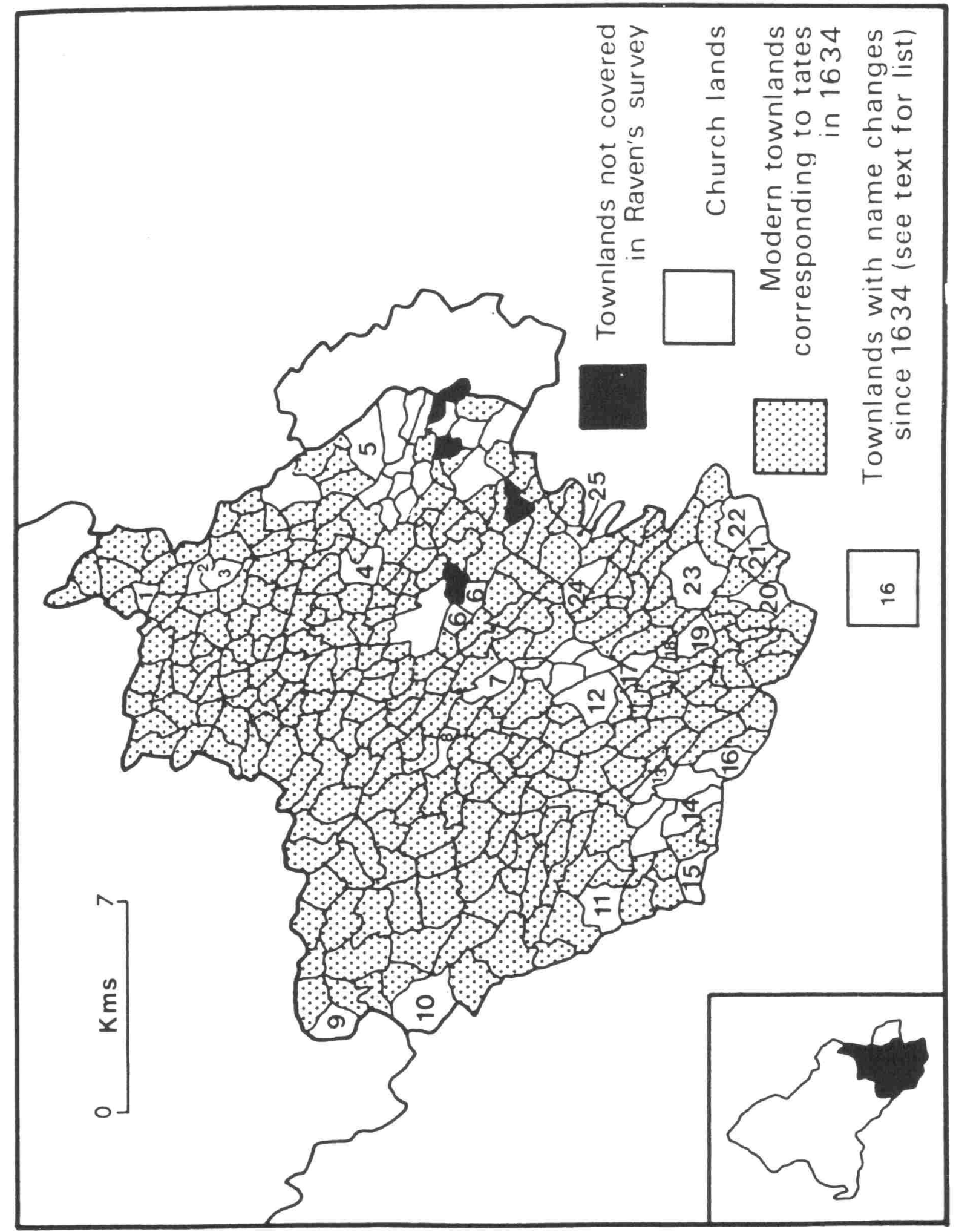

Fig. 1. The extent of Raven's Survey 1634-5. 


\section{Clogher Record}

there are comparatively few of these houses. Most of the two dozen in the maps are accounted for by a curious concentration in Peter's Town, where the houses and cabins are shown in a linear pattern along a street. Another concentration of houses, occurs in Carrickmacross and its environs which are not detailed in Fig. 2. In many cases, the isolated houses are shown with the owner's name, e.g., $\mathrm{Mr}$ Coop's House in Blittoge, Captain Mullenex's House in Annacroff and Coole McBryan's House just across the barony boundary in modern Tullygass townland. The latter's house is shown with what looks like lean-to outbuildings attached on one side. Another house, outside Carrickmacross, is listed as the Glebe of Dereolme.

Mills and churches were shown pictorially. The conventional symbol for mills was a building with half the water wheel shown. Some of the church buildings were depicted with 'gothic' style windows accompanied by 'Church at Magheracloney' or 'Mass House'. A considerable number of crosses were shown generally in twos and threes, possibly referring to graveyards (Fig. 2). In outline, the crosses look like celtic high crosses on pediments, but this may only have symbolic significance. Streams such as 'the great river of the fews' flowing from Muckno (with crude drawings of boats) are marked in, with quite a few springs, marked as 'tuber'. Fords and bridges are also represented quite realistically.

In addition a considerable number of forts are shown most of them pictorially represented as circular enclosures on top of hills, as they remain today throughout $\mathrm{Co}$. Monaghan. In the comparatively open and unenclosed landscape of Farney in 1634 , the hill-top raths must have made a striking impression and it is no wonder that Raven mapped many of them. In one instance there was a cabin shown inside the circular symbol; in general however the forts were quite separate from the dwellings. The forts were excluded from Fig. 2 because they were clearly inconsistently mapped, as a great many of the ring forts shown in the Ordnance Survey were not included. On the other hand, some of Raven's forts may not appear on the Ordnance maps.

A final interesting and tantalising feature in Raven's maps is the subdivisions within the tates : they are lettered, measured and referenced in tables on the back of the sheet according to land quality or land-use potential :"errable mixed with rushes", "moss and pasture", "rocke pasture" and a wide variety of other categories. Acreages of these subdivisions are given, although they look rather arbitrary, as the pecked-line boundaries seem unnaturally straight and geometric.

\section{The Settlement Pattern in 1634}

It might be suggested that Raven's details on settlement are not wholly reliable; that much of the detail is impressionistic and that in view of many of the empty spaces in Fig 2 he failed to record dwellings in many parts of the estate. That he visited all parts of the estate seems clear from the apparently accurate description of boundaries and the details on contiguous tates. It is possible, of course, that given the conditions of early seventeenth century Monaghan as we perceive them to have been, Raven might have missed some houses. We tend, however, to underestimate the 'normality' of life in the countryside at this time. Considering the detail of Raven's maps collectively, however, and the certainty with which his houses have been located, it is reasonable to assume that the survey is a fair representation of the distribution of settlement in Farney in 1634. As Andrews suggests about seventeenth century maps generally "their emptiness 


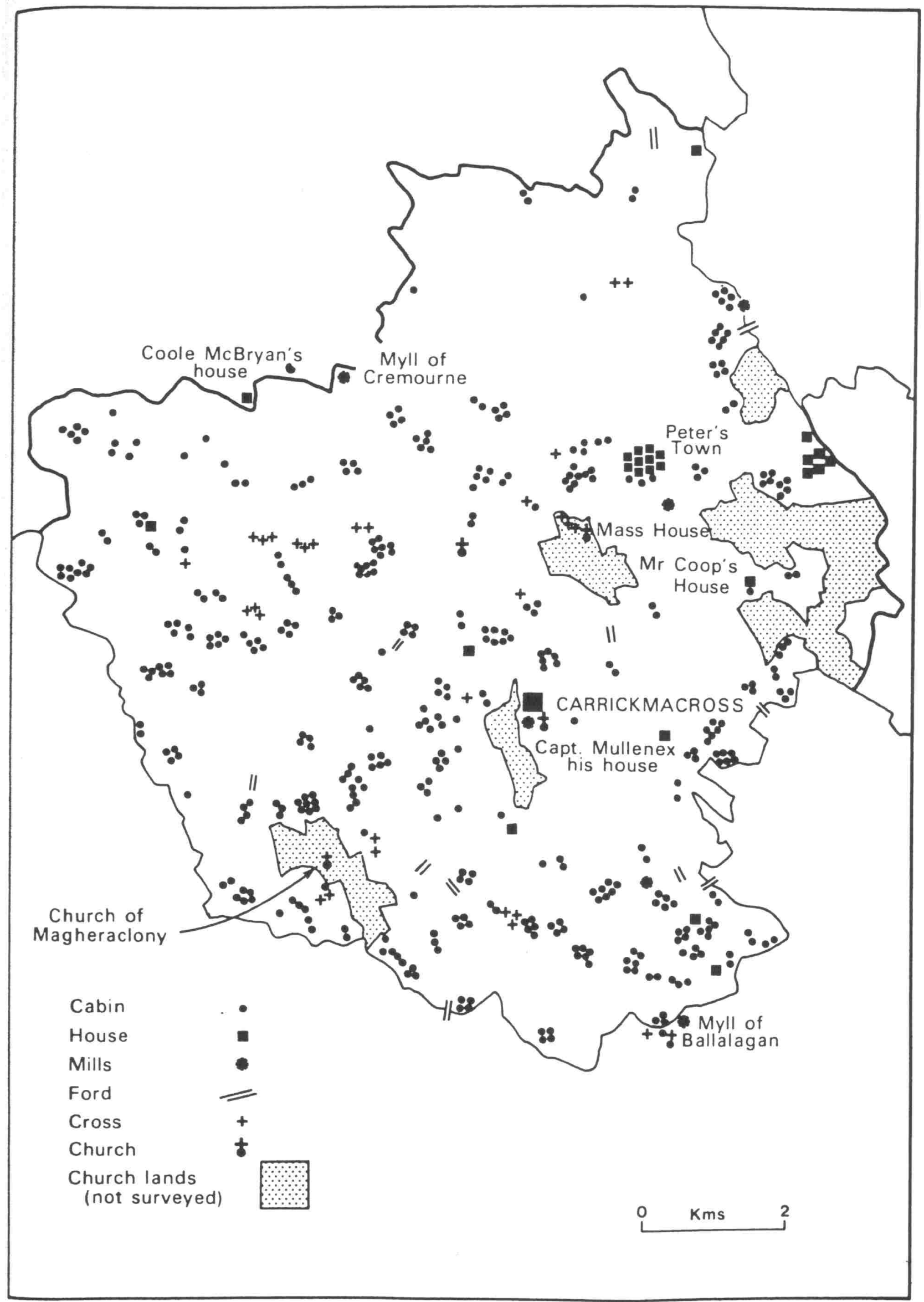

Fig. 2. The Settlement Pattern in 1634. 


\section{Clogher Record}

may well reflect the state of the landscape" ${ }^{18}$ before it began to fill up in the eighteenth century.

The accuracy of Raven's survey may be checked against two further sources of evidence for seventeenth century population. The 1659 'census' seems to be fairly complete for the barony of Farney. ${ }^{19}$ It may be used in conjunction with the Hearthmoney Roll for 1663 and $1665 .{ }^{20}$ Figs 3 and 4 show, therefore, areas which were inhabited in 1659 and 1663 and although there is certainly not a townlandby-townland correspondence with Raven's settlement in 1634, there is sufficient similarity in the general pattern of settlement to justify confidence in Raven's maps. The correspondence, or lack of it, between the patterns of settlement in 1634 and 1659 or 1665 , and its implications for change and continuity in a rural area like Farney in these traumatic twenty five years, is an interesting exercise that might be examined sometime.

Apart from extensive areas in the barony that were apparently uninhabited such as much of the north western part (in what was Donaghmoyne parish), the barony of Farney was generally quite densely populated. The emptiness of the south eastern corner of the estate is exaggerated largely by the presence of extensive church lands unsurveyed by Raven that were apparently well populated in 1665: Altogether there were over three hundred dwellings in the western half of the barony, which probably accounted for over one thousand people. The cabins were generally grouped in small clusters, with the bigger houses in more isolated locations. These latter may very well have been the houses that were specifically requested in the lease of the estate in 1618, many of which were probably destroyed in 1641, as some of their owners are listed among the beleaguered Protestants in Carrickmacross during the rising in October. ${ }^{21}$ Churches, probably reflecting the times, were comparatively few.

The settlement pattern needs to be studied in conjunction with the land-use divisions shown in the survey. Doubtless a systematic assessment of these divisions would be useful in throwing light on the intensity of settlement in each district. For example, many of the tates in the north of the barony appeared bleak and inhospitable in contrast to the much more varied land-use features in other districts.

An interesting aspect of Raven's survey is his omission of any reference to territorial units other than tates. As he was working in the Essex estate, boundaries apart from property boundaries were irrelevant to the survey. Parish boundaries, for example, were omitted. But, more significantly, he did not refer to ballybetaghs. These Gaelic 'estates' were universally significant in Monaghan in 1591 and 1606. It is ironic that while they continued in a disjointed and incomplete condition for the rest of the county in the later Book of Survey and Distribution, in Farney they are listed virtually intact. This continuity in Gaelic territorial order must be due in some way to the stability and unfragmented nature

18. Andrews, Irish Maps, 15.

19. S. Pender (ed) The 1659 Census, Dublin 1939.

20. Printed in Appendix 1 Rushe's History of Monaghan for Two Hundred Years, 291-338.

21. Shirley, Farney, 126. 
Farney in 1634: Raven's Survey

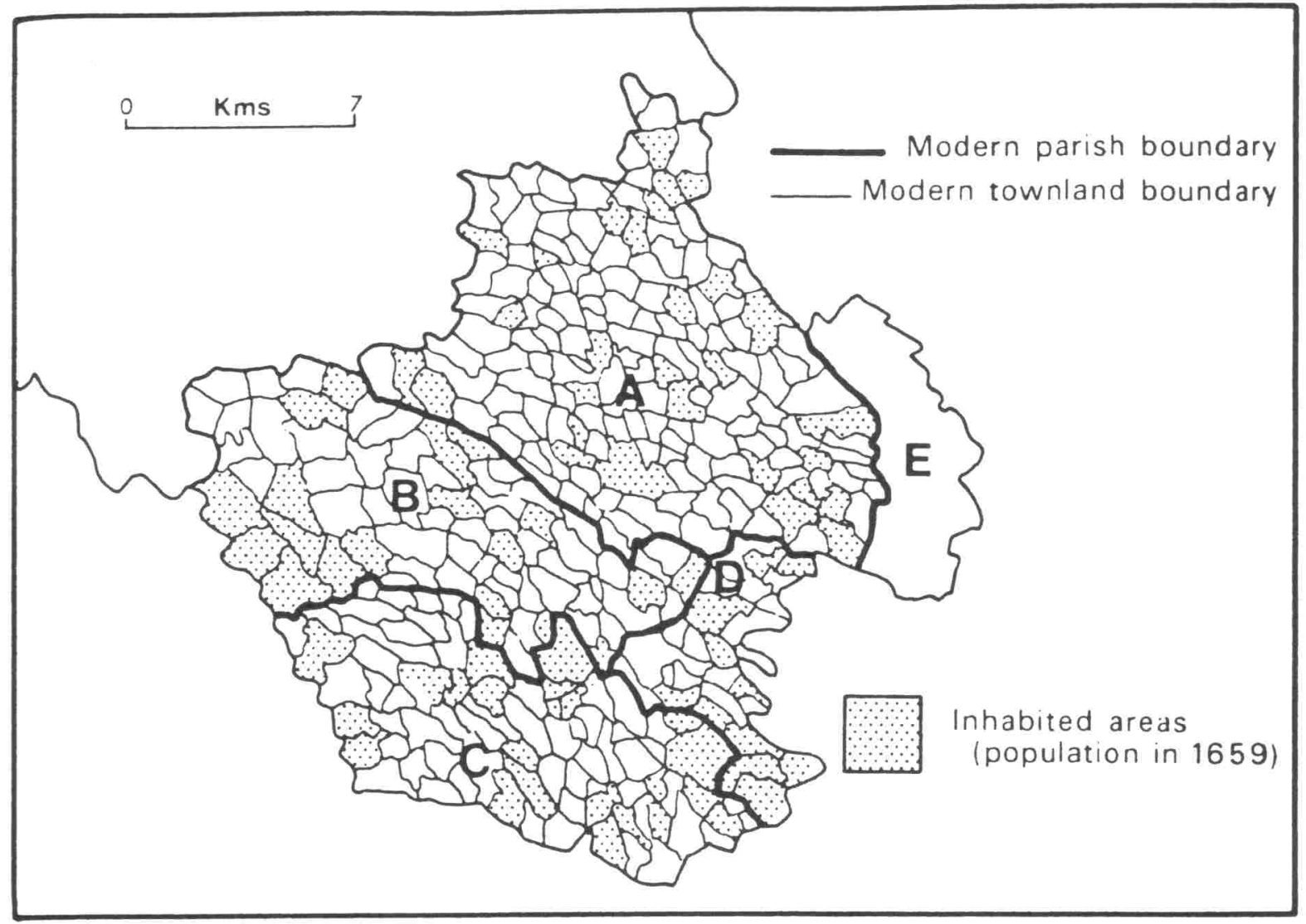

Fig. 3. The 1659 Census in Farney. A. Parish of Donaghmoyne,

B. Magheross, C. Magheracloone, D. Killanny (part of), E. Inniskeen (part of).

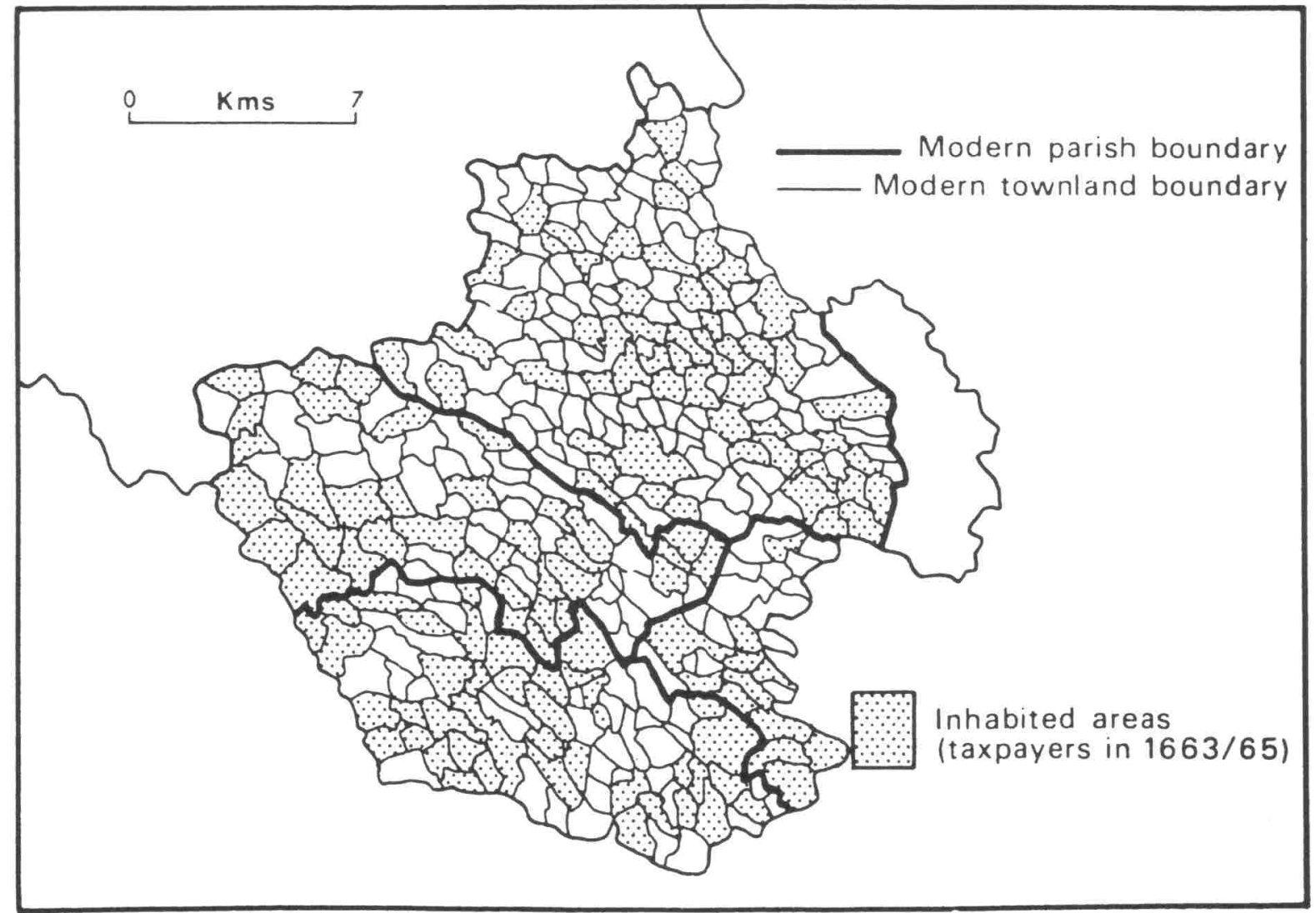

Fig. 4. The Hearthmoney Roll 1663-65. 


\section{Clogher Record}

of property ownership in Farney throughout the seventeenth century. ${ }^{22}$ But in 1634 , the delineation of these Gaelic units had little interest for Raven who was providing a survey for his English patron, for whom tates were the most useful native unit of land.

There is little doubt that Raven's survey of Farney throws considerable light on the nature of this south Ulster landscape in the early seventeenth century. Although a much more intensive and systematic analysis of his maps is necessary, it is clear even at this stage that in a region where Gaelic society and settlement was more or less still intact - some of the landowners who had featured in the 1591 and 1606 Divisions of Monaghan were still alive - Raven has described a well populated countryside, with a relatively dense network of highways and byeways and little evidence of any significant woodlands. Fig 2 shows what is clearly a lived-in landscape that is almost cluttered in places with habitations, mills, and some chapels. How stable was this settlement pattern? Fifty years earlier, would the pattern have been the same? The evidence of subsequent data sources confirms a certain stability through the turbulent mid seventeenth century period. In spite of the fact that most of the cabins were probably very impermanent structures, there is little reason to suspect that the 1634 pattern had changed radically in the previous thirty or forty years (see note ${ }^{15}$ ) : it probably formed the embryonic basis for the subsequent evolution of rural settlement in Farney into the eighteenth century. The general poverty of the region is undoubtedly indicated by the paucity of substantial houses - in contrast to other parts of the country where large stone houses (and castles) had been common for a long time.

The most important contribution of Raven's survey is the opportunity it provides to obtain fairly strong glimpses of the beginnings of the modern Monaghan landscape. Here we have what is an essentially Gaelic countryside, in which the living Gaelic language penetrates through placenames and occasional other references onto the vellum of Raven's maps. The poor clustered hamlets reflect the Gaelic mode of settlement in the shadows of the residual pattern of rath settlements of the medieval and earlier period. The peripheral mills presumably reflect the comparatively marginal impact of a grain economy in this poor region which its distinctively cattle-oriented local economy. These patterns of settlement were based on a communications net that shows significant parallels with the present day road network. Onto this landscape inherited from the sixteenth century, was being grafted in 1634 a new element that was to hasten and complete the modernisation of the Farney landscape. This intrusive landscape element was represented principally by the embryonic form of Carrickmacross town, with its castle, stone houses, rectangular allotments and predominantly Protestant planter population of butchers, merchants, land agents etc. The links between the little town and the surrounding countryside were presumably slight, represented mainly by a few country houses belonging to English undertakers mainly on the Essex estate and the church lands, links that were violently disrupted in 1641 when Carrickmacross became a very vulnerable and unsafe haven for the new Protestant settlers in Farney. Although Raven's survey has obvious limitations in

22. The persistence of such a complete record of ballybetaghs in Farney in the BSD is surprising given the eclipse of Gaelic landowning interests in Farney for so long - i.e. the septs or lineages to whom ballybetaghs were significant family lands had lost their rights to their properties technically since 1575 , but clearly since 1618 . 
what it can tell us about the social and economic circumstances of the time, his maps provide us with useful 'snapshots' of the south Monaghan landscape at a formative stage in its evolution.

Acknowledgement.

I am indebted to Professor John Andrews of Trinity College Dublin for first informing me of Raven's maps.

INDEX TO FIG. 1.

\section{Modern Townlands}

1. Gorteens

2. Knockreagh Lower

3. Knockreagh Upper

4. Lurganboys

5. Tattyboy

6. Longfield Etra Longfield Otra

7. Nafarty

8. Lisnaguiveragh

9. Carrickadooey

10. Cargaghoge

11. Scalkill

12. Doohatty

13. Knocknacran west

14. Lisnakeeny and Ballycartlan

15. Crumlin

16. Enagh

17. Ballyloughan and Liscorran
Equivalent Tates in Raven's Survey

Nagartan.

Tatereagh.

Dromreagh.

Tate of Lurganboys included a tate called Skeanagan, which contained Peter's Town.

Has subsumed the 1634 tates of Tate Reban, Shanvally als Tatanavally, Cargagh and Bealeacople, Tateboy.

Lamkill etra.

Lamkill otra.

Combines two tates called Farta and Farta Cavanrea.

Mullareagh als Lisnaduie

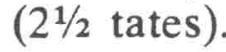

Kedentere.

Carighbeg.

Includes another tate called Cloughull.

Doate in 1634 also contained a tate called Kinnalege (als Killnalog).

Aughanara.

Lisnakin etra and Lisnakin otra.

Includes Lisnalun tate in 1634.

Cloonecon.

Balleloughan and Fartaballeloghan. 
Clogher Record

18. Leons Beg

19. Carrickadeshoge

20. Coolderry

21. Mullylusty, Clonmeenan and Creeveadornan

22. Annahean

23. Drumboory

24. Monaltyduff, Monaltybane

25. Coolaha
Ahalatafaren.

Carriagh.

'The Two Coole Ere's'

Were Mullaghloust and

Mullaghloust Moymuck.

Includes a small 1634 tate called Corcrehe.

Included a small tate called Tereneseskin.

All one tate called Moneleagh.

Clonkeagh. 